\title{
APLICACIÓN DE LA METODOLOGÍA DE REVISIÓN POR PARES EN DOCENCIA BILINGÜE
}

\section{APPLICATION OF PEER-REVIEWING METHODOLOGY IN BILINGUAL TEACHING}

\author{
María de la Paz Aguilar Caballos ${ }^{1}$, Ana María Ballesteros Gómez ${ }^{1}$, Juan José \\ Giner Casares ${ }^{2}$, Ángela Inmaculada López Lorente ${ }^{1}$, Rafael Lucena \\ Rodríguez ${ }^{1}$, Gustavo de Miguel Rojas ${ }^{2}$, Nieves Núñez Sánchez ${ }^{3}$, Víctor Manuel \\ Pavón Vázquez ${ }^{4}$ \& Antonio Di Pietro ${ }^{5}$
}

Fecha de recepción: 19/10/2019; Fecha de revisión: 28/11/2019; Fecha de aceptación: 21/02/2020

Cómo citar este artículo:

Aguilar, Ma P. et al. (2020). Aplicación de la metodología de revisión por pares en docencia bilingüe. Revista de Innovación y Buenas Prácticas Docentes, 9(1), 37-41.

\section{Autor de Correspondencia: jjginer@uco.es}

\section{Resumen:}

Este proyecto ha aplicado la metodología de revisión por pares para evaluar y mejorar la docencia en inglés de distintas asignaturas dentro del plan de bilingüismo de la Universidad de Córdoba. Se ha realizado la evaluación por parte de compañeros, la grabación de algunas clases, y una serie de sesiones presenciales en las que se han discutido los resultados y planteado puntos de mejora.

Palabras clave: Bilingüismo, Docencia en Inglés, Autoevaluación.

\section{Abstract:}

This project has applied the peer-review procedure to a group of professors teaching in the frame of the "Bilingualism Plan" of the University of Córdoba. Such lectures are taught entirely in English language. The Professors have evaluated each other after attending certain teaching sessions. A series of meetings for discussing the results have allowed concluding a number of recommendation points for improving the teaching in English language.

Key Words: Bilingualism, Teaching in English Language, Self-assessment.

\footnotetext{
${ }^{1}$ Departamento de Química Analítica, Universidad de Córdoba 2Departamento de Química Física, Universidad de Córdoba ${ }^{3}$ Departamento de Producción Animal, Universidad de Córdoba ${ }^{4}$ Departamento de Filologías Inglesa y Alemana, Universidad de Córdoba ${ }^{5}$ Departamento de Genética, Universidad de Córdoba
} 


\section{INTRODUCCIÓN}

El presente proyecto se enmarca dentro del "Programa de Fomento del Plurilingüismo en la Universidad de Córdoba" y responde a algunos objetivos del II Plan Estratégico 2016-2020 de nuestra Universidad, en consonancia con algunos informes internacionales sobre la calidad de la Educación Superior (European Comission, 2014; Henard \& Roseveare, 2012). La proyección de dichos planes se ha realizado a toda la Universidad, con un incremento de asignaturas ofertadas de 55 asignaturas en el pasado curso académico 2016/17 a 81 asignaturas en el presente curso académico 2017/18. El número de docentes se ha incrementado en cada curso, véase Figura 1.

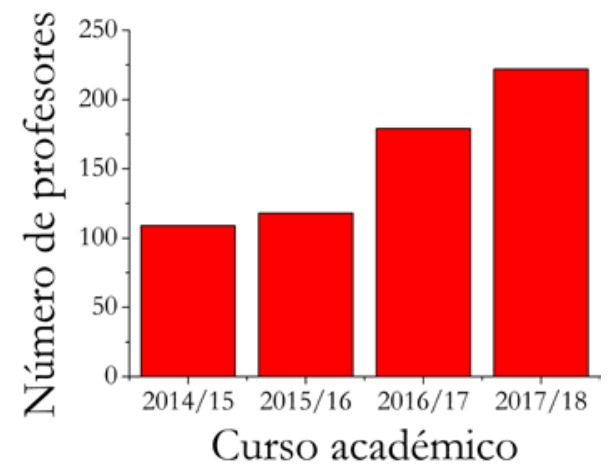

Figura 1. Evolución del número de profesores adscritos al Plan de Plurilingüismo de la UCO. Datos cedidos por el Prof. Dr. Antonio Raigón Rodríguez.

Es por ello que este proyecto incluye personal docente de distintas áreas de conocimiento y Facultades, en concreto: Facultad de Ciencias, Facultad de Veterinaria y Facultad de Filosofía y Letras. La multidisciplinaridad del equipo se entiende por tanto como un valor añadido de este proyecto, ya que los resultados serán en todo caso generales y aplicables a nivel de Universidad. El primer párrafo no tiene sangría. En la introducción se establece el marco teórico de la propuesta.

La "revisión por pares" se aplica de forma rutinaria para evaluar la idoneidad y calidad de artículos científicos en publicaciones internacionales y es aceptado como el sistema estándar de evaluación más objetivo. Este sistema de evaluación se ha aplicado con anterioridad en estudios con profesorado novel (Woodman \& Parappilly, 2015), en los que se ha concluido que las experiencias basadas en "revisión por pares" pueden modelar las prácticas docentes independientemente de la experiencia docente del profesorado implicado. El modelo de "revisión por pares" condujo a un análisis profundo del proceso de enseñanza-aprendizaje y a la obtención de mejoras notables en un período de tiempo relativamente corto.

Este proyecto ha usado dicho sistema entre los docentes implicados en el proyecto con independencia de su experiencia en la docencia universitaria bilingüe. Cabe destacar que las distintas materias impartidas por el profesorado participante en este proyecto requieren recursos y herramientas didácticas e instrumentos de evaluación diferentes. De esta forma, se han observado nuevos métodos de acercarse al uso del inglés en la docencia universitaria, así como se han encontrado dificultades inadvertidas y obtenidas soluciones a las mismas. El equipo docente del proyecto comparte el interés y la motivación por las competencias transversales relacionadas con el inglés como elemento de comunicación científica. Además, el profesorado participante tiene una trayectoria acreditable en el interés por el bilingüismo en nuestra Universidad. 


\section{DESARROLLO DE LA EXPERIENCIA DE INNOVACIÓN}

El procedimiento seguido durante el desarrollo del proyecto se resume a continuación, en orden cronológico:

M1: Sesión inicial de presentación y coordinación. Formación de pares de profesores en función de: asignaturas impartidas, horarios, campus. Confección de un modelo de rúbrica consensuado entre los profesores participantes.

M2: Visitas como observador no participante en todo caso de un miembro del grupo a una clase de grado de algún otro miembro. Se confeccionó un cuadrante, consensuado por todos los participantes en el proyecto, para que todos los miembros puedan realizar visitas a las sesiones de sus compañeros sin solapamiento con la propia docencia.

M3: Discusión por pares de las rúbricas en sesiones por parejas.

M4: Grabación en vídeo de algunas sesiones de clase. Los vídeos se han usado como material de estudio y discusión dentro del desarrollo de este proyecto, por lo que no se contempla la difusión de dichos vídeos fuera del proyecto.

M5: Sesión presencial final para establecer conclusiones del proyecto.

M6: Redacción de un catálogo con las conclusiones y recomendación de buenas prácticas para la enseñanza bilingüe desde el punto de vista de los resultados en la observación por pares.

M7: Grabación de un vídeo con el Aula Virtual de la Universidad de Córdoba para la difusión de los resultados e ideas más relevantes y que sean más directamente extrapolables al profesorado de la Universidad de Córdoba. En este apartado se describe la experiencia de innovación que se presenta. De igual forma que en el caso anterior, el primer párrafo no lleva sangría.

\section{RESULTADOS}

Los resultados obtenidos se discutieron en primera instancia por las parejas formadas para la observación por pares. A continuación, se realizó un listado de observaciones, aspectos extraordinariamente positivos del proceso docente y puntos de mejora que centralizó la colección de ideas. Estas ideas han sido agrupadas por temática, en función del aspecto docente al que se refieran. Dado que las sesiones de docencia han sido realizadas dentro del Plan de Bilingüismo de la Universidad de Córdoba, las discusiones e informes se han realizado en inglés, como se desarrolla a continuación.

\subsection{General}

In case of reduced groups or even individual lectures, the communication professorstudent is direct and is considered an added value for the lecture. The direct communication improves the motivation of the student. Those lectures taking place in the Chemistry Lab also especially motivate the students but the organization of the teaching spaces is not simple. 
An initial summary of the concepts presented in the previous session has been shown as a beneficial routine. Concerning the material given during the lecture to the students, a document where the primary information is presented (theory lecture) a protocol where all the experimental procedures are clearly indicated (lab lecture) is usually done by the professors. An alternative has been giving a handout to the students at the end of the lecture time to summarize all the key concepts developed during such session. Both presentations displayed using the beamer and writing on the blackboard along the class is used by the professors that participated in the project.

As a commonly found difficulty, the students in the Bilingualism Plan of the University of Córdoba have different backgrounds and therefore it is difficult to evaluate their individual levels.

The interaction with the students was promoted by asking relevant questions, as well as dividing the students into two working groups, and they collaborate to achieve the learning objectives. In some cases, the students seem to need more time than allowed for answering the questions.

\subsection{Make input comprehensible}

The PPT presentations and experimental protocols are provided in advance to the student. The Moodle platform is commonly used for this exchange of material. A brief overview of the acquired knowledge in previous lab sessions has been proven as beneficial for the learning of the students.

For lab sessions, starting with a discussion on general knowledge on the analytical procedures is recommended to catch the attention of the students. The peerreview observations indicate that starting the session with general knowledge (which analytes/samples, why they are important) instead of explaining the theory of the technique helps improving the motivation of the students.

\subsection{Use "teacher-talk" effectively}

This is a key point that is unfortunately refraining some students and even professors for participating in teaching in English language.

We have found that a certain slowing of the speech is usually advisable. It is also recommended to pronounce and explain abbreviations that are used along the lecture, e. g., LC (Liquid Chromatography) and MS (Mass Spectrometry).

A good practice that has been commonly observed in both theory and practical lectures is that the message was provided in three different ways: orally, in the PPT presentation and using a brief text. Moreover, during lab practice the messages are repeated in both general and personal level. The active usage of body language is also recommended.

\subsection{Promote student interactions}

The student interaction greatly differs from theory to lab lectures. Group work is inherent to the latter case. However, in theory lectures the class time is usually not enough to reach a significant level of interaction between the students. In this spirit, we suggest that the students should be given more time to answer and interact after a question. Yet, this point is difficult to implement due to the lack of time. A compromise solution should be found in this case. 
Motivating the students during interaction is also relevant. We have observed that replying encouraging sentences, e. g., "not exactly..." when students give wrong answers is beneficial for establishing a steady flow of interaction. Additionally, referring to a previous topic to make the students remind some concepts that they already know might be encouraging and can therefore enhance the interaction rate of the students.

The combined use of lecturing and interaction time is perceived as an element to promote the active participation of the students in the discussions.

The introduction of local information during the discussions, e. g., commonly used analytical techniques in Andalusian labs, might help to engage the students into the discussion.

\section{CONCLUSIONES}

Este proyecto ha permitido la observación por pares de compañeros docentes dentro del Plan de Bilingüismo de la Universidad de Córdoba. En primera instancia, las impresiones han sido muy buenas, ya que se ha atestiguado el excelente nivel docente por parte de otros compañeros. Además, durante las sesiones por parejas se han discutido aspectos específicos de cada asignatura observada, de forma que el docente ha podido incorporar directamente a su docencia aquellos consejos y recomendaciones ofrecidos por su pareja docente.

Se han determinado fortalezas y debilidades específicas en cada aspecto de la docencia en inglés, destacando la necesidad de promover la participación activa de los estudiantes durante las clases en inglés, véase las tres ideas principales expuestas en la sección anterior. Cabe destacar que éste es un aspecto necesario también en las clases en castellano, por lo que se ve agravado en las asignaturas bilingües.

Se ha realizado un vídeo explicativo del proyecto docente y de la extraordinaria experiencia de participar en el Plan de Bilingüismo de la Universidad de Córdoba con el Aula Virtual TV. Dicho vídeo a disposición de la comunidad universitaria en https://www.youtube.com/watch?v=LGoqWpf5k1E.

\section{REFERENCIAS}

Henard, F. \& Roseveare, D. (2012). Fostering quality teaching in higher education: policies and practices. An IHME Guide for Higher Education Institutions. IMHE: OECD.

Brusoni, M., Damian R., Grifoll Sauri, J., Jackson, S., Komürcügil, H., Malmedy, M., Matveeva, O., Motova, G., Pisarz, S., Pol, P., Rostlund, A., Soboleva, E., Tavares, O. \& Zobel, L. (2014). The concept of excellence in higher education. ENQA occasional papers.

European Commission (2014). Report on New modes of learning and teaching in higher education. High level group on the modernisation of higher education.

Woodman, R. J., \& Parappilly B. (2015). The efectiveness of peer review of teaching when performed between early-career academics. Journal of University Teaching of Learning Practice, 12 (1). 